\title{
BOARD OF DIRECTOR'S CHARACTERISTICS AND BANK PERFORMANCE: EVIDENCE FROM GCC REGION
}

\author{
Ehab R. Elbahar * \\ * American University in the Emirates, Dubai, UAE \\ Contact details: American University in the Emirates, Dubai Intl. Academic City, P.O. Box 503000, Dubai, UAE
}

OPEN ACCESS
How to cite this paper: Elbahar, E. R.
(2019). Board of director's characteristics
and bank performance: Evidence from
GCC region. Corporate Ownership \&
Control, 17(1), 14-23.
http://doi.org/10.22495/cocvl7ilart2
Copyright @ 2019 The Authors
This work is licensed under a Creative
Commons Attribution 4.0 International
License (CC BY 4.0).
https://creativecommons.org/licenses/by/
4.0/
ISSN Online: 1810-3057
ISSN Print: 1727-9232
Received: 24.06 .2019
Accepted: 03.09.2019
JEL Classification: M14, M40, M41, M42
DOI: 10.22495/cocv17ilart2

How to cite this paper: Elbahar, E. R. (2019). Board of director's characteristics GCC region. Corporate Ownership \& Control, 17(1), 14-23.

Copyright (C) 2019 The Authors

This work is licensed under a Creative Commons Attribution 4.0 International License (CC BY 4.0).

https://creativecommons.org/licenses/by/ DOI: $10.22495 /$ cocvlililart2

\begin{abstract}
The main purpose of the current study is to examine the association between Corporate Governance's (GC) variables represented by board characteristics and Bank performance measured by ROE and ROA in GCC banking sector. For the purposes of this study, the sample of 68 banks in gulf countries during the period from 2013 to 2017 have been selected and divided the data to Islamic banks and conventional banks (16 Islamic banks, 52 Non-Islamic). Furthermore this study uses the nonparametric regression OLS and Quantile analysis. The current study suggest that the existence of female directors on the board of director in last years is significantly associated with better performance, we concludes that females in GCC banking sector in latest years reached a high level of maturity in understanding banking industry. Furthermore, this study suggests that the audit committee associated positively and significantly with bank performance, it means that the audit committee in latest years plays important role in enhancing the performance. In addition to the above, the political member on the board and risk committee does not affect the performance significantly. Both of board size and Sharia committee are associated positively and significantly with performance.
\end{abstract}

Keywords: Corporate Governance, Board of Directors Characteristics, Gender Diversity, Audit Committee, Islamic and Conventional Banks, GCC Countries, Bank Performance

Authors' individual contribution: The author is responsible for all the contributions to the paper according to CRediT (Contributor Roles Taxonomy) standards.

\section{INTRODUCTION}

Corporate governance is addressed widely during the past years in the business universe by all stakeholders such as regulators, financial and capital market participants, central banks and shareholders around the world. This addressing is due to the vital and important role of corporate governance in achieving the strategic and operational objectives of business firms.

The global financial scandals and crises influenced and emphasized the vital role of boards of directors and senior management in mitigating the risks and enhance the corporate governance and internal control systems which in return enhance the returns and performance.
COSO defined corporate governance as the system of rules, practices, and processes by which a firm is directed and controlled. Furthermore, corporate governance essentially involves balancing the interests of a company's many stakeholders, such as shareholders, management, customers, suppliers, government and the community. Additional to the above, the IIA defined corporate governance as a relationship between all business stakeholders. In addition, corporate governance establishes the structure in light of goals and objectives and determines the means of achieving those objectives and monitoring the performance.

As per the literature review, it is obvious that better corporate governance leads to better performance. In this regard, several authors studied 
this relationship and highlighted the importance of board characteristics and their implication on performance. A vital question in this study is about the maturity and the evolution of corporate governance especially boar characteristics in last years during the period from 2013 to 2017.

The main principles of strong corporate governance are; transparency, accountability, fairness, and responsibility, in banking sector these principles are vital in giving legitimacy on corporate level (OECD, 2004). In agreement with this concept, the World Bank Report (2006) mentioned that these principles have a strong implication on banking sector and economic growth. Additional to the above, one of the main roles of corporate governance is to make sure that all major stakeholders receive relevant and reliable information in relation to the value of the firm, furthermore, the corporate governance should motivate the management to maximize firm value instead of focusing on personal goals (Luo, 2005).

In reference to the structure of the firm and as per the effective corporate governance, the firm's structure must reflect the strategic and operation goals and determine the tools of achieving those goals. In addition, the board of director has an oversight role in monitoring the performance (Basel Committee on Banking Supervision Principles for enhancing corporate governance in October 2010). The concept of corporate governance extends and expands more than what is mentioned above to include several components such as; board composition, board size, existence of independent directors; composition of various committees of the board; and separation of chair of the board and CEO, Anand (2005).

The current study aims to fill the literature gap by providing empirical evidence of the maturity and evolution of board characteristics and its relationship with bank performance measured by ROE and ROA using a sample of GCC banks over the period from 2013 till 2017. Furthermore, this study includes the following sections. The literature review and hypotheses development will be presented in Section 2. Section 3 presents the research design and methodology followed by results and discussion in Sections 4. Conclusion of this study is presented in Section 5 .

\section{LITERATURE REVIEW AND HYPOTHESIS DEVELOPMENT}

As per the review of previous literature, different results can be noted about the association between Board characteristics and performance whereas a number of researchers found a positive relationship with bank performance, and other researchers found that this relationship is negative, and others found that no association.

Gulamhussen and Santa (2015) noted that there is a significant and positive association between the existence of female members and performance. In consistence with the same result, Low et al. (2015) concluded that there is positive and significant association between performance measured by ROE and the existence of increasing number of female on the board. Furthermore, García-Mecaa et al. (2015) reached the same result which is the gender diversity increases bank performance. In the same context, Kenyanya et al. (2017) noted that the board gender diversity positively and significantly influences the valueadded performance. Owen and Temesvary (2018) concluded that there is positive association between the existence of female members in the board and bank performance, this observation is only noted in better-capitalized banks. Bennouri et al. (2018) found that female directorship significantly increases ROA and ROE, and significantly decreases Tobin's Q. Conyon and He (2017) concluded that the presence of female members on the board has a positive effect on firm performance.

In contrast with the above researchers, Wachudi and Mboya (2012) concluded that board gender diversity has no significant effect on bank performance. Hoque and Muradoglu (2013) concluded the same result whereas the existence of female directors does not add any value to the board. In the same line, Al-Musallia and Ismail (2012) concluded that gender diversity is not associated with IC performance. Sunday and Godwin (2017) concluded that no significant relationship between board gender diversity and financial performance. Qamar et al. (2016) noted that the presence of females as a director on board is not helpful or fruitful for betterment of corporate governance. Al-Yahyaee et al. (2017) concluded that the presence of female members in the boards suppresses the positive association between corporate governance and market risk disclosures. As per their analysis, this result is due to the culture and conservatism nature of GCC societies in business universe. Sherif and Anwar (2016) concluded that gender diversity decreases bank performance in MENA. Darmadi (2013) noted that the female members in the board of director associated negatively with firm performance measured by (ROA and Tobin's Q). Abobakr (2017) indicated that the existence of female members has no effect on bank performance.

Regarding non-executives, the independent board members are associated significantly with better bank performance measured by ROE (Brown \& Caylor, 2004). In the same line, Al-Hawary (2011) found that higher percentage of non-executive directors significantly associated with better performance. Busta (2007) reached the same result in number in Europe countries (France, Germany, Italy, and Spain).

In reference to board size, there are numbers of studies agree on the positive association with performance, while another group of studies disagrees with this positive association. Hermalin and Weisbach (2001), Uwuigbe (2012), Bohren and Strom (2007), Denis and de Andres et al. (2005) and McConnell (2003) concluded that this correlation with performance is negative. In the same line Bennedsen et al. (2004) concluded the same result between board size and performance which is negative and significant.

Chen et al. (2015) provided evidence that there is a positive relationship between audit committee and earnings in Japanese firms. In contrast, Durgavanshi, (2014) concluded that there is no significant association between audit committee and performance. In the same line, Klein (2002) and Fanta et al. (2013) noted that the audit committee significantly and negatively affects bank performance. In reference to risk committee, Battaglia et al. (2015) concluded that there is positive relationship between risk committee size and banks ROE and ROA. 
Hermalin and Weisbach (2001) and Huson et al. (2001) concluded that the board replaces poorly performing CEOs to enhance and develop the firm's performance. Huson et al. (2004), Borokhovich et al. (1996) and Farrell and Whidbee (2003) concluded that the association between CEO turnover and performance is significant and positive when the CEO departures were followed by the appointment of a new CEO from outside the firm.

Arouri et al. (2014) concluded that the association between government ownership, CEO duality and board size with performance is insignificant. Furthermore, Basuony et al. (2014) indicated that there is a significant association between corporate governance and bank profitability. Board size and a number of outside directors significantly affect Tobin's Q, and the ROA and PM are affected by audit committee, audit committee meetings, and the age and size of the bank.

\section{RESEARCH DESIGN AND METHODOLOGY}

This section presents the data collection, sample, models, definitions and measurement of dependent and independent variables.

\subsection{Sample and data collection}

In order to test the hypothesis of the current study, we use data of 68 banks from the GCC region for the period from 2013 to 2017 . We gathered the data from the annual reports of selected banks. To examine the association between board characteristics and Bank performance we employ the following model:

$$
\begin{array}{r}
\text { ROE }=\beta 0+\beta 1 \text { Bsize }+\beta 2 N E B M+\beta 3 \text { Audcom }+\beta 4 \text { Creditcom }+\beta 5 \text { Riskcom }+\beta 6 \text { CEOturn }+\beta 7 \text { Gender } \\
+\beta 8 \text { Govown }+\beta 9 \text { Banksize }+\beta 10 \text { Btype }+\beta 11 \text { Shariacom }+\beta 12 \text { umpolitical }+\varepsilon \\
\text { ROA }=\beta 0+\beta 1 \text { Bsize }+\beta 2 N E B M+\beta 3 \text { Audcom }+\beta 4 \text { Creditcom }+\beta 5 \text { Riskcom }+\beta 6 \text { CEOturn }+\beta 7 \text { Gender } \\
+\beta 8 \text { Govown }+\beta 9 \text { Banksize }+\beta 10 \text { Btype }+\beta 11 \text { Shariacom }+\beta 12 N \text { umpolitical }+\varepsilon
\end{array}
$$

\subsection{Dependent variable}

The dependent variable in the current study is bank performance measured by the proxy variable ROE and ROA. Return on Equity (ROE) measures the profitability of the business based on the equity of the firm. This percentage measures how well firms are employing investments in order to generate and keep earnings growth. Return on Assets (ROA), this ratio measures efficiency and effectiveness of firms in generating returns on their economic resources.

\subsection{Independent variables}

In this study we used 12 independent variables classified into two groups. The first group is board characteristics variables: percentage of nonexecutive directors, gender diversity, board size, CEO-Turnover, existence of BOD committees such as audit committee, risk committee, credit \& investment committee and Sharia Committee and number of political members. The second group is control variables: bank type (Islamic and conventional), ownership structure (government ownership), firm size (bank size). Table 1 shows the definition of current study variables.

Table 1. Definition and measurement of variables

\begin{tabular}{|l|l|l|}
\hline \multicolumn{1}{|c|}{ Variable } & \multicolumn{1}{c|}{ Definition } & \multicolumn{1}{c|}{ Measurement } \\
\hline Bsize & Board size & Total number of board members \\
\hline NEBM & Percentage of non- executives & $\begin{array}{l}\text { The ratio of non-executive directors to the total number of } \\
\text { directors on the board }\end{array}$ \\
\hline Audcom & Audit committee & 1 if there is audit committee and 0 if otherwise \\
\hline Riskcom & Risk committee & 1 if there is risk committee and 0 if otherwise \\
\hline Creditcom & Credit and investment committee & $\begin{array}{l}1 \text { if there is credit and investment committee and } 0 \text { if } \\
\text { otherwise }\end{array}$ \\
\hline Shariacom & Sharia committee & 1 if there is sharia committee and 0 if otherwise \\
\hline CEOturn & CEO turnover & 1 if it is the first year of CEO, 0 if otherwise \\
\hline Gender & Gender diversity & 1 if there is female on the board, and 0 if otherwise \\
\hline Govown & Governmental ownership & 1 if the government owns more than $50 \%$ and 0 if otherwise \\
\hline Banksize & Bank size & The logarithm of total assets \\
\hline Btype & Bank type & 1 if Islamic bank and 0 if otherwise \\
\hline ROA & Return on assets & Bank's net income / total assets \\
\hline ROE & Return on equity & Bank's net income to total equity \\
\hline Numpolitical & Number of political members on the board & Total number of political members on the board \\
\hline
\end{tabular}

\section{RESULTS AND DISCUSSION}

STATA statistical computer package has been used in the current study to analyze and test the hypotheses. We use the Multivariate and bivariate analysis to address the association between the dependent variable and all independent variables.

\subsection{Descriptive statistics}

Table 2 presents the descriptive statistics of the independent variables. As mentioned in the table, the range of non-executives is between $44 \%$ (min) and $100 \%$ (max), while its mean is $92.8 \%$ which considered a high percentage. The average board size is 9.197, and the range is between 4 members (min) and 16 members (max). Furthermore, the number of political members on the board of 
directors is between 0 and 6 members and the mean is lower than one member which is 0.873 .

As indicated in Panel B, Islamic banks represent $23.6 \%$ and the conventional banks represent $76.4 \%$ of the total sample. Furthermore, government banks represent $20.6 \%$ and the nongovernment banks represent $79.4 \%$ out of the total sample.
As per Panel B, 23.9\% of the sample allocated for female members and $76.1 \%$ for male members which reflect the culture of GCC countries. In addition to the above, $98.6 \%$ of the sample has audit committees and $84.5 \%$ has risk committee and $34.4 \%$ has credit and investment committee. 100\% of Islamic banks include Sharia committee which is in conformance with central banks' requirements.

Table 2. Descriptive statistics

\begin{tabular}{|c|c|c|c|c|c|c|c|}
\hline \multicolumn{8}{|c|}{ Panel A: Descriptive statistics for regression variables } \\
\hline Variable & Obs. & Mean & Min. & Max. & Std. Dev. & Skewness & Kurtosis \\
\hline Bank size & 340 & 16.561 & 10.08 & 20.514 & 2.3981 & 0.102 & 0.026 \\
\hline Board size & 340 & 9.197 & 4 & 16 & 1.8781 & 0.623 & 0.057 \\
\hline Non-executives \% & 340 & 0.928 & 0.440 & 1 & 0.098 & 0.014 & 0.024 \\
\hline No. of political members & 340 & 0.873 & 0 & 6 & 1.5434 & 0.102 & 2.325 \\
\hline ROA & 340 & 0.011 & -0.3670 & 0.102 & 0.0287 & 1.235 & 4.020 \\
\hline ROE & 340 & 0.095 & -0.395 & 0.290 & 0.0749 & 0.021 & 3.256 \\
\hline \multicolumn{8}{|c|}{ Panel B: Descriptive statistics of dummy variables } \\
\hline \multicolumn{3}{|c|}{ Variable } & & & \multicolumn{2}{|r|}{$\%$} \\
\hline \multirow{3}{*}{\multicolumn{3}{|c|}{ Bank type }} & & & 260 & \multicolumn{2}{|r|}{76.4} \\
\hline & & & 1 & \multicolumn{2}{|r|}{80} & \multicolumn{2}{|r|}{23.6} \\
\hline & & & & \multirow{2}{*}{\multicolumn{2}{|c|}{340}} & & \\
\hline \multirow{3}{*}{ Government ownership } & & & 0 & & & \multicolumn{2}{|r|}{79.4} \\
\hline & & & 1 & \multicolumn{2}{|r|}{$\frac{270}{70}$} & \multicolumn{2}{|r|}{20.6} \\
\hline & & & & \multicolumn{2}{|r|}{340} & & \\
\hline \multirow{3}{*}{ Gender diversity } & & & 0 & \multicolumn{2}{|r|}{259} & \multicolumn{2}{|r|}{76.1} \\
\hline & & & 1 & \multirow{2}{*}{\multicolumn{2}{|c|}{$\begin{array}{c}81 \\
340\end{array}$}} & \multicolumn{2}{|r|}{23.9} \\
\hline & & & & & & \\
\hline \multirow{3}{*}{ CEO turnover } & & & 0 & \multicolumn{2}{|r|}{301} & \multicolumn{2}{|r|}{88.5} \\
\hline & & & 1 & \multicolumn{2}{|r|}{39} & & 11.5 \\
\hline & & & & & 340 & & \\
\hline & & & 0 & & 5 & & 1.4 \\
\hline Audit committee & & & 1 & & 335 & & 98.6 \\
\hline & & & & & 340 & & \\
\hline & & & 0 & & 223 & & 65.6 \\
\hline Credit and investment committee & & & 1 & & 117 & & 34.4 \\
\hline & & & & & 340 & & \\
\hline & & & 0 & & 53 & & 15.5 \\
\hline Risk committee & & & 1 & & 287 & & 84.5 \\
\hline & & & & & 340 & & \\
\hline & & & 0 & & 255 & & 75 \\
\hline Sharia committee & & & 1 & & 85 & & 25 \\
\hline & & & & & 340 & & \\
\hline
\end{tabular}

As mentioned in Table 2 Panel A, some variables are skewed which means that we need to pay more attention through the analysis process. For regression analysis purposes, we used STATA software, and based on STATA, we employed a number of graphical and numerical methods. Furthermore, to check the multicollinearity we employed correlation coefficients and Variance Inflation Factors (VIF) with tolerance values. The results of the VIF and correlations coefficients give assurance that there is no multicollinearity. Gujarati
(2003) indicates that there are no issues if the VIF is lower than 10. (Groebner et al., 2005) indicated that other authors suggest that the value of 5 could be based as a rule of thumb. The maximum VIF in the current study is 2.46, while 1.62 is the mean of VIF which confirm our conclusion that there is no multicollinearity in the current study. Additional to the above, Table 3 (Panel A and Panel B) presents Pearson correlation coefficients and Spearman correlation coefficient between the independent variables and dependent variable (respectively). 
Table 3. Correlation matrix

\begin{tabular}{|c|c|c|c|c|c|c|c|c|c|c|c|c|c|c|}
\hline \multicolumn{15}{|c|}{ Panel A: Pearson correlation matrix } \\
\hline & Btype & Bsize & Govown & Boardsize & NEBM & Gender & CEOturn & Audcom & Credcom & RiskCom & Shariacom & Numpolitical & ROA & ROE \\
\hline Btype & 1 & & & & & & & & & & & & & \\
\hline Bsize & -0.0808 & 1 & & & & & & & & & & & & \\
\hline Govown & $-0.111^{\text {** }}$ & $0.177^{* * * * *}$ & 1 & & & & & & & & & & & \\
\hline Boardsize & 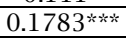 & -0.0189 & 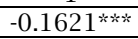 & 1 & & & & & & & & & & \\
\hline NEBM & 0.084 & $0.215^{* * * *}$ & $0.219^{\ldots \ldots * *}$ & $0.096^{*}$ & 1 & & & & & & & & & \\
\hline Gender & $-0.099 *$ & $-0.151^{* * * *}$ & $0.091 *$ & $0.206^{* \ldots * * \ldots}$ & 0.0685 & 1 & & & & & & & & \\
\hline CEOturn & 0.018 & -0.068 & 0.045 & 0.002 & 0.0602 & 0.0587 & 1 & & & & & & & \\
\hline Audcom & 0.068 & -0.028 & 0.062 & -0.078 & 0.0303 & 0.0683 & 0.044 & 1 & & & & & & \\
\hline Credcom & $0.138^{* * \pi}$ & 0.008 & 0.029 & 0.023 & $0.3001^{* \cdots * 2}$ & -0.0272 & -0.0470 & 0.0885 & 1 & & & & & \\
\hline Riskcom & $0.124^{* *}$ & $0.107^{* \mathrm{k}}$ & 0.078 & 0.037 & $0.2493^{* * * *}$ & 0.0119 & 0.0529 & 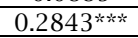 & $0.2942^{\cdots \cdots *}$ & 1 & & & & \\
\hline Shariacom & $0.961^{* \ldots * * *}$ & $-0.119^{* * *}$ & $-0.127^{\text {**k }}$ & $0.166^{* * * * * *}$ & 0.0674 & -0.0688 & 0.0687 & 0.0708 & $0.1097^{* * \mathrm{k}}$ & $0.1179^{* * *}$ & 1 & & & \\
\hline Numpolitical & -0.067 & $0.383^{* \ldots * *}$ & $-0.128^{* *}$ & -0.019 & 0.0188 & $-0.1378^{* * *}$ & -0.0064 & -0.0893 & -0.0892 & 0.0384 & -0.0859 & 1 & & \\
\hline$R O A$ & -0.007 & $0.322^{\ldots * *}$ & 0.033 & 0.000 & -0.0199 & -0.0770 & -0.0302 & -0.0005 & 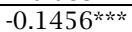 & -0.058 & -0.0107 & 0.0869 & 1 & \\
\hline$R O E$ & $-0.0935 *$ & $0.4627^{\cdots \cdots * *}$ & 0.0514 & -0.0110 & 0.0031 & $-0.1940^{* \ldots * * \mathrm{k}}$ & $-0.0902 *$ & 0.0408 & -0.0313 & -0.0426 & $-0.0923^{*}$ & $0.1334^{* * *}$ & $0.6679^{* * * *}$ & 1 \\
\hline \multicolumn{15}{|c|}{ Panel B: Spearman correlation matrix } \\
\hline & Btype & Bsize & Govown & Boardsize & NEBM & Gender & CEOturn & Audcom & Credcom & Riskcom & Shariacom & Numpolitical & ROA & ROE \\
\hline Btype & 1 & & & & & & & & & & & & & \\
\hline Bsize & -0.0888 & 1 & & & & & & & & & & & & \\
\hline Govown & $-0.1119 * * \ldots$ & $0.1988^{\text {块茫 }}$ & 1 & & & & & & & & & & & \\
\hline Boardsize & 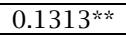 & 0.0014 & $-0.1309^{* *}$ & 1 & & & & & & & & & & \\
\hline Nexc & 0.0379 & 0.0428 & $0.2406^{* * * *}$ & $0.1311^{* * *}$ & 1 & & & & & & & & & \\
\hline Gender & $-0.0996^{*}$ & $-0.1632^{* \ldots * *}$ & $0.0901^{*}$ & $0.2336^{* \ldots *}$ & 0.0695 & 1 & & & & & & & & \\
\hline CEOturn & 0.0173 & -0.0745 & 0.0445 & -0.0215 & 0.0763 & 0.0581 & 1 & & & & & & & \\
\hline Audcom & 0.068 & -0.009 & 0.0624 & $-0.1003^{*}$ & 0.0528 & 0.0686 & 0.0441 & 1 & & & & & & \\
\hline Credcom & $0.1372^{* * \mathrm{k}}$ & 0.0219 & 0.0282 & 0.0053 & $0.3304^{* * * *}$ & -0.0285 & -0.0478 & 0.0888 & 1 & & & & & \\
\hline Riskcom & $0.1245^{* * k}$ & $\begin{array}{l}0.0818 \\
\end{array}$ & 0.0791 & 0.0372 & $0.2273^{* \ldots * \mathrm{k}}$ & 0.0126 & 0.0534 & $0.2842^{* * * *}$ & $0.2954^{* * * *}$ & 1 & & & & \\
\hline Shariacom & 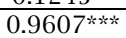 & $-0.1302^{\cdots * *}$ & $-0.127^{\text {菂 }}$ & $0.1186^{\text {*k }}$ & 0.0322 & -0.0688 & 0.0687 & 0.0708 & $0.1097^{* \ldots *}$ & $0.1179^{* * *}$ & 1 & & & \\
\hline Numpolitical & -0.089 & 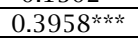 & -0.0779 & -0.0324 & 0.0212 & $-0.1233^{\text {米 }}$ & -0.0429 & 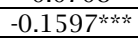 & -0.0009 & 0.0391 & $-0.1107^{* \ldots * *}$ & 1 & & \\
\hline$R O A$ & $-0.112^{* * *}$ & $0.4269^{* * * * *}$ & -0.0049 & 0.0755 & 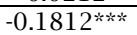 & 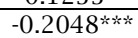 & $-0.172^{* \ldots * * *}$ & 0.0498 & $-0.0911^{*}$ & -0.0807 & $-0.1369 * *$ & 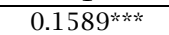 & 1 & \\
\hline$R O E$ & $-0.1014^{*}$ & $0.3937^{* * * *}$ & 0.0432 & $0.104^{*}$ & -0.0431 & $-0.2121^{\text {***k }}$ & $-0.1439^{* \ldots * *}$ & $0.0896^{*}$ & 0.0038 & -0.0266 & $-0.1073^{\text {*** }}$ & $0.1424^{* * * *}$ & $0.638^{* * * k}$ & 1 \\
\hline
\end{tabular}

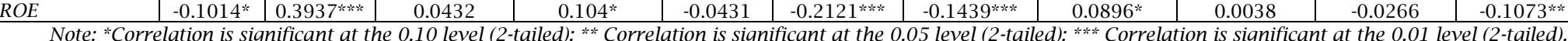




\subsection{Multivariate analysis}

To ensure that the results are not method driven but are robust across methods it is recommended to use several approaches. In the current study to analyze our data and test our model, we run two different types of regression analysis; Ordinary Least Squares regression (OLS) and Quantile data regression. OLS is more commonly used and considered linear regression and simple or multiple depending on the number of explanatory variables. Quantile regression method as a robust regression analysis represents an example of techniques that not focus on the sum of squared errors as in OLS but focus on minimizing the sum of absolute residuals. Furthermore, Quantile regression focuses on the median and help in estimating either the conditional median or other quantiles of the response variable. In addition to the above, quantile regression is considered an extension of linear regression. The results of the OLS and Quantile regression methods of the current study are presented in Tables 4 and 5 .

As indicated in Table 4, the presence of female members on the board of director affects positively the profitability of the GCC banking sector represented by ROE. Furthermore, this result reflects the positive enhancement level in maturity and evolution of the role of female members in BOD during last years compared to the results of previous studies whereas (Elbahar et al., 2016) indicated that there is week evidence that the existence of female members affects positively the performance and risk management of banks. In addition to the above, Table 4 shows that the board size is associated positively and significantly with ROE at $1 \%$ level, this result means that the large board size the large ROE. While Table 5 indicated that there is no significant relationship between board size and ROA.

As mentioned in Table 4 the relationship between the audit committee and ROE is positive and significant in both OLS and Quantile tests at 5\% and $1 \%$ respectively. Furthermore, as mentioned in
Table 5, the association between audit committee and ROA is positive and significant in the Quantile tests at $1 \%$ and insignificant in OLS test.

As per Table 4 and 5 , the existence of political members on the board of directors in all tests are insignificant with ROE and ROA, we can explain this result that the change in ROE or ROA cannot be explained by any change in the existence of political members in GCC banking sector.

Regarding risk committee and as per Table 5 its association with ROA is insignificant, but as mentioned in Table 4 this association is negative and significant at 10\% significance level with ROE using OLS test and this association is insignificant under Quantile test.

Using the OLS and Quantile test, Sharia committee variable is associated significantly and positively with ROE at $10 \%$ and $1 \%$ respectively, while this association is insignificant with ROA.

As per the Quantile test, we can note that the replacement of the CEO is negatively and significantly associated with ROA and ROE at $1 \%$ and $10 \%$ significance level. We can explain this result that the replacement of CEO is associated with better bank performance measured by ROE and ROA.

Furthermore, the relationship between the nonexecutive board member and ROE and ROA is negative and significant at a 99\% confidence level. This result can be explained as the higher percentage of non-executive members associated with lower return on assets and equity.

In reference to control variables, we noted that the association of bank size in all tests is positive and significant with ROE and ROA. Regarding bank type, the association with ROE is negative and significant which means that Islamic banks are associated with higher ROE and conventional banks are associated with lower ROE. In addition to the above, government ownership is insignificant in all tests except for the association with ROA using Quantile test which is negative and significant which means that government banks are associated with better ROA.

Table 4. Regression results using ROE

\begin{tabular}{|c|c|c|c|c|}
\hline \multirow{2}{*}{ Variables } & \multicolumn{2}{|c|}{ OLS } & \multicolumn{2}{|c|}{ Quantile } \\
\hline & Coef. & $P>t$ & Coef. & $P>t$ \\
\hline Bank type & -0.0645555 & 0.040 & -0.07629 & 0.001 \\
\hline Bank size & 0.0153621 & 0.000 & 0.012606 & 0.000 \\
\hline Government ownership & -0.0009094 & 0.925 & -0.01061 & 0.192 \\
\hline Board size & 0.0023501 & 0.248 & 0.007535 & 0.000 \\
\hline NEBM & -0.0470327 & 0.250 & -0.08472 & 0.01 \\
\hline Gender diversity & -0.0268775 & 0.003 & -0.02170 & 0.004 \\
\hline CEO turnover & -0.0134648 & 0.240 & -0.01790 & 0.061 \\
\hline Audit committee & 0.0614304 & 0.050 & 0.074963 & 0.002 \\
\hline Credit and investment committee & 0.0000378 & 0.996 & 0.013919 & 0.047 \\
\hline Risk committee & -0.0191415 & 0.081 & -0.01036 & 0.250 \\
\hline Sharia committee & 0.0515024 & 0.093 & 0.066958 & 0.002 \\
\hline No. of political members & -0.0029442 & 0.256 & 0.003072 & 0.160 \\
\hline _cons & -0.1684864 & 0.002 & -0.1575 & 0.000 \\
\hline $\mathbf{R}^{2}$ & \multicolumn{2}{|c|}{0.270} & \multirow{2}{*}{\multicolumn{2}{|c|}{0.1463}} \\
\hline Pseudo R ${ }^{2}$ & & & & \\
\hline
\end{tabular}


Table 5. Regression results using ROA

\begin{tabular}{|c|c|c|c|c|}
\hline \multirow{2}{*}{ Variables } & \multicolumn{2}{|c|}{ OLS } & \multicolumn{2}{|c|}{ Quantile } \\
\hline & Coef. & $P>t$ & Coef. & $P>t$ \\
\hline Bank Type & -0.004 & 0.759 & -0.00035 & 0.890 \\
\hline Bank size & 0.004391 & 0.000 & 0.001882 & 0.000 \\
\hline Government ownership & -0.00092 & 0.819 & -0.00178 & 0.037 \\
\hline Board size & 0.000235 & 0.781 & 0.000294 & 0.108 \\
\hline NEBM & -0.01283 & 0.451 & -0.02242 & 0.000 \\
\hline Gender diversity & -0.00226 & 0.542 & -0.00113 & 0.158 \\
\hline CEO turnover & -0.00106 & 0.823 & -0.003 & 0.003 \\
\hline Audit committee & 0.008448 & 0.516 & 0.00741 & 0.004 \\
\hline Credit and investment committee & -0.00786 & 0.022 & -0.001 & 0.173 \\
\hline Risk committee & -0.00458 & 0.315 & -0.00069 & 0.473 \\
\hline Sharia committee & 0.00678 & 0.595 & -0.0014 & 0.573 \\
\hline No. of political members & -0.00115 & 0.288 & -0.00015 & 0.510 \\
\hline _cons & -0.05169 & 0.021 & -0.00359 & 0.443 \\
\hline $\mathbf{R}^{2}$ & \multicolumn{2}{|c|}{0.1381} & & \\
\hline${\text { Pseudo } \mathbf{R}^{2}}^{2}$ & & & \multicolumn{2}{|c|}{0.1414} \\
\hline
\end{tabular}

Table 6. A summary of results

\begin{tabular}{|c|c|c|c|c|c|c|}
\hline \multicolumn{7}{|c|}{ Panel A: Association with $R O E$} \\
\hline \multirow{2}{*}{ Independent variables } & \multicolumn{4}{|c|}{ Bivariate analysis } & \multirow{2}{*}{ OLS } & \multirow{2}{*}{ Quantile } \\
\hline & Pearson & Spearman & T-test & Mann Whitney & & \\
\hline Bank type & $(-) *$ & $(-) *$ & $(+)^{* * * *}$ & $(+)^{*}$ & $(-)^{* * *}$ & $(-) * * *$ \\
\hline Bank size & $(+)^{* * * *}$ & $(+)^{* * * *}$ & & & $(+)^{* \cdots * * *}$ & $(+)^{* * * *}$ \\
\hline \multicolumn{7}{|l|}{ Government ownership } \\
\hline Board size & & $(+)^{*}$ & & & & $(+)^{* \ldots+* *}$ \\
\hline NEBM & & & & & & $(-)^{* * * *}$ \\
\hline Gender diversity & $(-)^{* * * * *}$ & $(-)^{* * * * *}$ & $(+)^{* 2 \% * 2}$ & 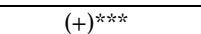 & $(-)^{* * * \%}$ & $(-) * * *$ \\
\hline CEO turnover & $(-)^{*}$ & $(-)^{* * * *}$ & $(+)^{* *}$ & $(+)^{* * * *}$ & & $(-)^{*}$ \\
\hline Audit committee & & $(+)^{*}$ & & & $(+)^{* *}$ & $(+)^{* * * *}$ \\
\hline $\begin{array}{l}\text { Credit and investment } \\
\text { committee }\end{array}$ & & & & & & $(+)^{* *}$ \\
\hline Risk committee & & & & & $(-)^{*}$ & \\
\hline Sharia committee & $(-)^{*}$ & $(-)^{* * *}$ & $(+)^{* * *}$ & $(+)^{* * *}$ & $(+)^{*}$ & $(+)^{* \cdots * * *}$ \\
\hline No. of political members & $(+)^{* * *}$ & $(+)^{* * *}$ & & & & \\
\hline \multicolumn{7}{|c|}{ Panel B: Association with ROA } \\
\hline \multirow{2}{*}{ Independent variables } & \multicolumn{4}{|c|}{ Bivariate analysis } & \multirow{2}{*}{ OLS } & \multirow{2}{*}{ Quantile } \\
\hline & Pearson & Spearman & T-test & Mann Whitney & & \\
\hline Bank type & & $(-)^{* *}$ & & $(+)^{* * *}$ & & \\
\hline Bank size & $(+) * * *$ & $(+)^{* * * *}$ & & & $(+)^{* \ldots * *}$ & $(+)^{* * * * *}$ \\
\hline Government ownership & & & & & & $(-)^{* * *}$ \\
\hline \multicolumn{7}{|l|}{ Board size } \\
\hline NEBM & & $(-)^{* * * *}$ & & & & $(-)^{* * * *}$ \\
\hline Gender diversity & & $(-)^{* * * *}$ & $(+)^{*}$ & $(+)^{* * * *}$ & & \\
\hline CEO turnover & & $(-)^{* * * *}$ & & $(+)^{* * * *}$ & & $(-)^{* * * *}$ \\
\hline Audit committee & & & & & & $(+)^{* * * *}$ \\
\hline $\begin{array}{l}\text { Credit and investment } \\
\text { committee }\end{array}$ & $(-)^{* * * *}$ & $(-)^{*}$ & $(+)^{* \cdots *}$ & & $(-)^{* * *}$ & \\
\hline \multicolumn{7}{|l|}{ Risk committee } \\
\hline Sharia committee & & $(-)^{* * *}$ & & $(+)^{* * *}$ & & \\
\hline No. of political members & & $(+)^{* * 2 * *}$ & & & & \\
\hline
\end{tabular}

\section{CONCLUSION}

The current study investigates the relationship between corporate governance represented by board characteristics variables and bank performance represented by ROE and ROA, moreover this study focuses on investigating the evolution and the maturity level of a number of variables in GCC banking sector in last years such as gender diversity, a number of political members on board, board size, CEO turnover, nonexecutives, existence of Sharia committee, audit committee and risk committee and credit and investment committee. Furthermore, it examined the association between government ownership, bank type (Islamic and conventional) and bank size with bank performance. The current study uses a sample of 340 observations from 68 banks in GCC banking sector. The results provide evidence that the existence of female members on the board of director in last years is significantly associated with better performance at $1 \%$ significance level, from this result we conclude that females in last years reached a good level of maturity related to deep understanding of banking industry and how to add value to boards of directors by enhancing the banks' performance. Furthermore, the association between board size and performance is positive and significant at $1 \%$ significance level. Regarding the existence of political members on the board and bank performance, we noted that the change in performance cannot be explained by the change in political members' number. Based on all analytical tests of this study, we concluded that the Sharia committee is associated significantly and positively with $\mathrm{ROE}$ at $10 \%$ and $1 \%$ respectively, while this association is insignificant with ROA.

In reference to the role of audit committee, this study suggests that its association with ROE and ROA is positive and significant which means that the audit committee in banking sector in latest years plays important role in enhancing the performance, 
on the other hand, and comparing to the previous results of other studies, the board of director got matured enough in understanding the banking industry. Furthermore, the association between risk committee and bank performance is insignificant which means that the change in performance cannot be explained by the change in risk committee, on the other hand, risk committees in GCC banking sector are not playing significant role in maximizing the returns.

In relation to the replacement of the CEO, it is negatively and significantly associated with ROA and ROE at $1 \%$ and $10 \%$ significance level. We can explain this result that the replacement of the CEO is associated with better bank performance. Furthermore, we concluded that the relationship between a non-executive board member and performance is negative and significant, which could be explained that the higher percentage of nonexecutive members are associated with lower return on assets and equity.

Regarding the control variables, this study concludes that the association of bank size is positive and significant with bank performance, this result agrees with so many previous studies. Furthermore, Islamic banks are associated with higher ROE but regarding conventional banks, it is associated with lower ROE. In addition to the above, government ownership is insignificantly associated with performance.

The current study contributes to the corporate governance especially the BOD characteristics literature by filling the gaps in literature in the GCC banking sector. In addition, this study provides reasonable evidence that there obvious maturity and evolution in number of explanatory variables such as the role of female members on BOD and the role of audit committees in enhancing banks' performance. Based on this study results, we can suggest that these results could be generalized in countries that have similar cultural and regulatory environments and factors. Furthermore, some other explanatory factors need more efforts to affect the performance positively such as; political members, risk committee and non-executive members.

In reference to the limitations of the current study, it could be covered by future research to explore and follow up the maturity and evolution level of number of BOD's characteristics such as; gender diversity, political members, CEO turnover, non-executive members, board size, existence of Sharia committee, audit committee and risk committee and credit and investment committee.

Mainly in the current study, there are two limitations that need to be considered in the preceding research. First, this study relies and focuses mainly on quantitative data, not the qualitative data such as interviews, questionnaire, and surveys. The qualitative method aims to test empirically the association between corporate governance and performance. So we suggest that uses of both quantitative and qualitative methods should enrich the results and help to deeply understand the board of director characteristics. Second, this study focuses mainly on secondary data, however, the primary data could be a useful tool if employed and accompanied by secondary data. We exerted so many efforts to use a questionnaire as a source of primary data however; the banks' response rate was very low. That is why we decided to rely on secondary data only.

From the above limitations, we suggest some skylines and Ideas for future research. First, this study investigated the association between board characteristics and performance during the period from 2013 to 2017, our advice for the future research is to investigate the maturity and evolution of corporate governance after the abovementioned period.

Second, our results referred that there is positive evolution for both of the role of female members on the board and the role of audit committee toward the performance, our advice is to continue investigating the maturity of the other variables in the coming years. Furthermore, future researchers can investigate more committees' characteristics such as member's experience, qualification, age and number of meetings. Third, in this study we used the ROE and ROA as proxy variables for performance, we advise for future studies to select more performance variables such as productivity, liquidity, marketability and human resources.

\section{REFERENCES}

1. Abobakr, M. (2017). Corporate governance and bank performance: Evidence from Egypt. Asian Economic and Financial Review, 7(12), 1326-1343. https://doi.org/10.18488/journal.aefr.2017.712.1326.1343

2. Alfiero, S., Cane, M., Doronzo, R., \& Esposito, A. (2018). The effect of national cultural differences of board members on integrated reporting. Corporate Board: Role, Duties and Composition, 14(1), 7-21. http://doi.org/ $10.22495 /$ cbv14ilart1

3. Al-Hawary, S. (2011). The effect of banks governance on banking performance of the Jordanian commercial banks: Tobin's Q model “An applied study”. International Research Journal of Finance and Economics, 71, 3447. Retrieved from https://www.researchgate.net/publication/289782208_The_effect_of_banks_governance _on_banking_performance_of_the_Jordanian_commercial_banks_Tobin's_Q_model_an_applied_study

4. Al-Musallia, M., \& Ismail, K. (2012). Intellectual capital performance and board characteristics of GCC banks. Procedia Economics and Finance, 2, 219-226. https://doi.org/10.1016/S2212-5671(12)00082-2

5. Al-Yahyaee, K., Al-Hadi, A., \& Hussain, S. (2017). Market risk disclosures and board gender diversity in Gulf Cooperation Council (GCC) firms. International Review of Finance, 17(4), 645-658. https://doi.org/ $10.1111 /$ irfi.12123

6. Amore, M., \& Garofalo, O. (2016) Executive gender, competitive pressures, and corporate performance. Journal of Economic Behavior \& Organization, 131, 308-327. https://doi.org/10.1016/j.jebo.2016.09.009

7. Arouri, H., Hossain, M., \& Muttakin, M. B. (2014). Effects of board and ownership structure on corporate performance: Evidence from GCC countries. Journal of Accounting in Emerging Economies, 4(1), 117-130. https://doi.org/10.1108/JAEE-02-2012-0007 
8. Atkins, J., Zakari, M., \& Elshahoubi, I. (2018). Implementing the board of directors' mechanism - An empirical study of the listed firms in Libya. Corporate Board: Role, Duties and Composition, 14(1), 22-33. http://doi.org/ $10.22495 /$ cbv14ilart2

9. Asaoka, D. (2018). Collective intelligence or groupthink? Group decision making under the Japanese Companies Act. Corporate Board: role, duties and composition, 14(2), 27-37. http://doi.org/ $10.22495 /$ cbv14i2art3

10. Baloyi, S. L., \& Ngwakwe, C. C. (2017). Chief executive officer's gender and firm performance in the JSE SRI firms. Corporate Board: role, duties and composition, 13(1-1), 73-78. http://doi.org/10.22495/cbv13ilclart1

11. Basuony, M., Mohamed, E. K. A., Al-Baidhani, A. M. (2014). The effect of corporate governance on bank financial performance: evidence from the Arabian Peninsula. Corporate Ownership \& Control, 11(2-1), 178-191. https://doi.org/10.22495/cocv11i2c1p3

12. Battaglia, F., \& Gallo, A. (2015) Risk governance and Asian bank performance: An empirical investigation over the financial crisis. Emerging Markets Review, 25, 53-68. https://doi.org/10.1016/j.ememar.2015.04.004

13. Bennedsen, M., Kongsted, H. C., \& Nielsen, K. M. (2004). Board size effects in closely held corporations (CAM Institute of Economics, University of Copenhagen Working Paper No. 25). Retrieved from https://www.researchgate.net/publication/5094287_Board_Size_Effects_in_Closely_Held_Corporations

14. Bennouri, M., Chtioui, T., Nagati, H., \& Nekhili, M. (2018). Female board directorship and firm performance: What really matters? Journal of Banking and Finance, 88, 267-291. https://doi.org/10.1016/ j.jbankfin.2017.12.010

15. Borokhovich, K. A., Parrino, R., \& Trapani, T. (1996). Outside directors and CEO selection. Journal of Financial and Quantitative Analysis, 31(3), 337-355. https://doi.org/10.2307/2331395

16. Brown, L. D., \& Caylor, M. L. (2004). Corporate governance and firm performance. https://doi.org/ $10.2139 /$ ssrn. 586423

17. Chen, J., Duh, R. R., Hsu, A. W. H., \& Pan, C. M. (2015) Can Anglo-Saxon audit committee scheme improve earnings quality in non-Anglo-Saxon environments? Journal of Contemporary Accounting \& Economics, 11(1), 61-74. https://doi.org/10.1016/j.jcae.2014.12.004

18. Conyon, M., \& He, L. (2017). Firm performance and boardroom gender diversity: A quantile regression approach. Journal of Business Research, 79, 198-211. https://doi.org/10.1016/j.jbusres.2017.02.006

19. Darmadi, S. (2013). Do women in top management affect firm performance? Evidence from Indonesia Corporate Governance: The International Journal of Business in Society, 13(3), 288-304. https://doi.org/ 10.1108/CG-12-2010-0096

20. Durgavanshi, S. (2014). Impact of corporate governance practices on financial performance of microfinance institutions in India. https://doi.org/10.2139/ssrn.2636047

21. Elbahar, E., El-Masry, A. A., \& Abdelfattah, T. (2016). Corporate governance and risk management in GCC banks. Corporate Ownership \& Control Journal, 13(3), 8-16. https://doi.org/10.22495/cocv13i3p1

22. Fanta, A., Kemal, K., \& Waka, Y. (2013). Corporate governance and impact on bank performance. Journal of Finance and Accounting, 1(1), 19-26. https://doi.org/10.11648/j.jfa.20130101.12

23. Farrell, K. A., \& Whidbee, D. A. (2003). Impact of firm performance expectations on CEO turnover and replacement decisions. Journal of Accounting and Economics, 36(1), 165-196. https://doi.org/10.1016/ j.jacceco.2003.09.001

24. García-Meca, E., García-Sánchez, I. M., \& Martínez-Ferrero, J. (2015). Board diversity and its effects on bank performance: An international analysis. Journal of Banking \& Finance, 53, 202-214. https://doi.org/ 10.1016/j.jbankfin.2014.12.002

25. Ghazalat, A. N. M., Islam, Md. A., Noor, I. B. M., \& Abu Haija, A. A. (2017). Does the competency attributes of board members' enhance the monitoring of earning management? Evidence from a developing country. Corporate Board: role, duties and composition, 13(1-1), 100-108. http://doi.org/10.22495/cbv13ilclart4

26. Gulamhussen, M. A., \& Santa, S. F. (2015). Female directors in bank boardrooms and their influence on performance and risk-taking. Global Finance Journal, 28, 10-23. https://doi.org/10.1016/j.gfj.2015.11.002

27. Hermalin, B. E., \& Weisbach, M. S. (2001). Boards of directors as an endogenously determined institution: A survey of the economic literature (National Bureau of Economic Research Working Paper No. 8161). https://doi.org/10.3386/w8161

28. Hoque, H., \& Muradoglu, G. (2013). Bank boards, CEO characteristics and performance: Evidence from large global banks during the crisis. Retrieved from https://scholar.google.com/citations?user= wfw9tKEAAAAJ\&hl=en

29. Huson, M. R., Parrino, R., \& Starks, L. T. (2001). Internal monitoring mechanisms and CEO turnover: A long-term perspective. The Journal of Finance, 56(6), 2265-2297. https://doi.org/10.1111/0022-1082.00405

30. Iskandrani, M., Yaseen, H., \& Al-Amarneh, A. (2018). Executive compensation and corporate performance: Evidence from Jordanian commercial banks. Corporate Board: role, duties and composition, 14(2), 38-44. http://doi.org/10.22495/cbv14i2art4

31. Jadah, H., Murugiah, L., \& Abdul Adzis, A. (2016). Board characteristics and bank performance: Evidence from Iraq. Journal of Independent Studies and Research: Management, Social Sciences and Economics, 14(1), 29-41. https://doi.org/10.31384/jisrmsse/2016.14.1.3

32. Kenyanya, P., Ombok, B., \& Mule, R. (2017). Board composition and value-added performance in an emerging securities market: Panel evidence from Kenya. Scholars Journal of Economics, Business and Management, 4(11), 822-827. Retrieved from http://saspjournals.com/wp-content/uploads/2017/11/SJEBM-411822-827.pdf

33. Khan, M., Fraz, A., Hassan, A., \& Abedifar, P. (2018). Board gender diversity, risk taking and performance: Evidence from dual banking systems (Centre for Responsible Banking \& Finance Working Paper No. 19-003). https://doi.org/10.2139/ssrn.3302475

34. Low, D. C., Roberts, H., \& Whiting, R. H. (2015). Board gender diversity and firm performance: Empirical evidence from Hong Kong, South Korea, Malaysia and Singapore. Pacific-Basin Finance Journal, 35, 381-401. https://doi.org/10.1016/j.pacfin.2015.02.008

35. Modiba, E. M., \& Ngwakwe, C. C. (2017). Women on the corporate board of directors and corporate sustainability disclosure. Corporate Board: role, duties and composition, 13(2), 32-37. http://doi.org/ $10.22495 /$ cbv13i2art3

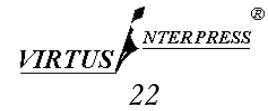


36. Owen, A., \& Temesvary, J. (2018). The performance effects of gender diversity on bank boards. Journal of Banking \& Finance, 90, 50-63. https://doi.org/10.1016/j.jbankfin.2018.02.015

37. Qamar, M. A. J., Khalil, F., \& Akhtar, W. (2016). Corporate governance culture transmission in mutual funds: Directors as vector of transmission. International Journal of Academic Research in Accounting, Finance and Management Sciences, 6(2), 175-183. https://doi.org/10.6007/IJARAFMS/v6-i2/2138

38. Ren, T., \& Wang, Z. (2011) Female participation in TMT and firm performance: Evidence from Chinese private enterprises. Nankai Business Review International, 2(2), 140-157. https://doi.org/10.1108/20408741111139918

39. Sherif, M., \& Anwar, S. (2016). Board structure, gender diversity and bank performance in emerging markets: Evidence from the MENA region. Paper presented at ISBE Conference. Retrieved from https://www.researchgate.net/publication/299445582

40. Sila, V., Gonzalez, A., \& Hagendorff, J. (2016) Women on board: Does boardroom gender diversity affect firm risk? Journal of Corporate Finance, 36, 26-53. https://doi.org/10.1016/j.jcorpfin.2015.10.003

41. Skala, D., \& Weill, L. (2018). Does CEO gender matter for bank risk? Economic Systems, 42(1), 64-74. https://doi.org/10.1016/j.ecosys.2017.08.005

42. Sunday, O., \& Godwin, O. (2017). Effects of board globalizing on financial performance of banks in Nigeria. International Journal of Academic Research in Accounting, Finance and Management Sciences, 7(4), 1-10. https://doi.org/10.6007/IJARAFMS/v7-i4/3304

43. Wachudi, E. J., \& Mboya, J. (2012). Effect of board gender diversity on the performance of commercial banks in Kenya. European Scientific Journal, 8(7), 128-148. http://doi.org/10.19044/esj.2012.v8n7p\%25p

44. Weisbach, M. S. (1988). Outside directors and CEO turnover. Journal of financial Economics, 20, 431-460. https://doi.org/10.1016/0304-405X(88)90053-0 